\title{
ANALISIS PENGGUNAAN BAHASA INDONESIA LARAS HUKUM PADA PUTUSAN PERKARA EKONOMI SYARIAH PENGADILAN AGAMA MAKASSAR
}

Edhy Rustan*

Edhy_rustan@yahoo.co.id

\begin{abstract}
Abstrak
Penelitian ini bertujuan mendeskripsikan bentuk-bentuk kesalahan pengunaan bahasa Indonesia laras hukum dalam putusan perkara ekonomi syariah pada Pengadilan Agama Makassar. Penelitian merupakan penelitian deskriptif kualitatif yang bersifat dokumentatif atau penelitian pustaka (library research). Data dalam penelitian ini adalah penggunaan bahasa hukum pada putusan perkara ekonomi syariah nomor 73/Pdt.G/2015/PA.Mks. pengadilan Agama Makassar. Pengumpulan data dilakukan melalui teknik dokumentasi, dengan menelaah beberapa referensi tentang penguaan bahasa hukum, baik yang berupa buku, jurnal, majalah, koran, laporan hasil penelitian, maupun dokumen-dokumen hukum yang relevan dengan permasalahan yang diteliti. Pencatatan yaitu penulis mencatat semua hal yang berhubungan dengan fenomena pengunaan bahasa hokum, yang diperoleh dari putusan pengadilan Agama Makassar serta dokumen-dokumen yang relevan, ke dalam buku catatan yang telah dipersiapkan dalam bentuk korpus data. Langkah-langkah analisis data, yaitu (1) Mengidentifikasi bahasa hukum yang mengalami kesalahan, (2) Mengklasifikasi bentuk kesalahan penulisan kalimat dalam putusan perkara ekonomi syariah Pengadilan Agama Makassar, (3) Menganalisis bentuk kesalahan pengunaan bahasa Indonesia yang berbentuk kalimat dalam putusan perkara ekonomi syariah Agama Makassar, (4) Mendeskripsikan setiap bentuk kesalahan pengunaan bahasa yang disertai uraian-uraian atau penjelasan. Hasil penelitian diperoleh bahwa, kalimat bahasa Indonesia laras hukum dalam putusan perkara ekonomi syariah Pengadilan Agama Makassar mengalami kesalahan struktur sebagai akibat tidak memiliki fungsi subjek dalam kalimat, dan pengunaan konjungsi yang tidak tepat, serta tidak memerhatikan penulisan tanda baca, diksi, kata bermakna ambigu, pengunaan kata mubazir, serta menyesuaikan konteks perkara dengan pola penalaran yang tepat. Sebagai akibat dari kesalahan tersebut, makna kalimat menjadi rancu, sehingga sulit dipahami oleh pembaca. Selain itu, kesalahan struktur kalimat dapat menyebabkan perbedaan makna yang ditumbulkan dalam suatu putusan.
\end{abstract}

Kata kunci: Bahasa, Hukum, Ekonomi Syariah

\section{Pendahuluan}

Bahasa Indonesia sebagai suatu bahasa yang berkembang memunyai banyak ragam, masing-masing berfungsi dalam proses komunikasi. Sesungguhnya, setiap ragam bahasa yang terdapat dalam bahasa Indo-nesia adalah sejajar. Artinya, tidak ada laras atau ragam yang lebih baik atau lebih betul dari yang lainnya (Said, 2004: 7). Bahasa Indonesia dalam perundangundangan pada dasarnya hanya merupakan salah satu ragam bahasa yang tidak banyak berbeda dengan ragam bahasa Indonesia yang lain. Yang membedakan ragam ini dengan ragam yang lain hanyalah terletak pada (1) format penyajian yang khas dan (2) pemakaian kata/istilah tertentu beserta ter- minologinya, sedangkan kaidah yang lain, yaitu kegramatikalan kalimat dan penulisannya tetap harus tunduk pada kaidah yang ada. Dengan kata lain, bahasa yang digunakan dalam perundang-undangan haruslah menggunakan ragam bahasa baku atau standar. Bahasa baku atau standar ialah bahasa yang dapat dijadikan acuan atau tolok ukur, baik dalam hal kegramatikalan kalimat mencakup struktur kalimat serta bentuk dan pilihan kata maupun dalam hal penulisannya.

Penggunaan istilah bahasa hukum bukanlah secara linguistik, melainkan secara sosiologis. Alasannya, bahasa hukum Indonesia adalah bahasa nasional Indonesia yang dipergunakan dalam penyusunan produk hukum tertulis (perundang-undangan), yuris- 
prudensi, tuntutan hukum (requisitor), pembelaan, syarat-syarat dalam perkara perdata dan lain-lain, maupun yang berwujud keterampilan penggunaan bahasa dalam profesi (hukum) seperti konseptor-konseptor rancangan perundang-undangan, hakim, jaksa, pengacara, notaris dan lain-lain (Said, 2006:136). Jadi, bahasa Indonesia yang digunakan dalam bidang hukum ialah Bahasa Indonesia hukum atau bahasa hukum Indonesia. Dalam symposium bahasa dan hukum disimpulkan bahwa bahasa Indonesia hukum ialah bahasa Indonesia yang digunakan dalam bidang hukum, yang mengingat fungsinya mempunyai karakteristik tersendiri (BPHN (Ed), 1976:106).

Bahasa dan hukum memiliki hubungan yang sangat erat. Hukum merupakan peraturan yang mengatur kelakuan, perbuatan, tindakan, dalam kehidupan masyarakat. Tanpa hukum, masyarakat akan kacau. Sementara aturan atau peraturan itu dinyatakan dengan bahasa, yaitu bahasa hukum. Bahasa dan hukum merupakan penjelasan kehidupan manusia dalam masyarakat yang merupakan penjelmaan dari suatu kebuda yaan pada suatu tempat dan waktu. Dalam hubungan suatu masyarakat dan kebudayaan tertentu, bahasa dan hukum saling berhubungan dan berpengaruh satu dengan yang lainnya. Bahkan, kebudayaan harus dianggap sebagai penjelmaan masyarakat dan kebudayaan itu, yang sebaliknya dipengaruhi pula oleh bahasa maupun oleh hukum (Alisjahbana dalam Badudu, 1993: 42).

Hubungan yang erat antara bahasa dan hukum seperti yang dilukiskan oleh Alisjahbana di atas, memang sangatlah tidak mungkin untuk diabaikan. Dalam masyarakat mana pun, hukum sebagai salah satu sarana untuk menciptakan keteraturan dan ketertiban sosial, dirumuskan utamanya melalui bahasa walaupun ada simbol-simbol lain yang juga penting untuk menetapkan hukum. Hukum hanya dapat berjalan efektif apabila ia dirumuskan dengan tegas dan mencerminkan nilai-nilai yang hidup dalam masyarakat, dan harus dapat dikomunikasikan dengan baik pada subjek-subjek hukum yang dituju. Apabila anggota masyarakat tidak memahami makna ketentuan yang dirumuskan dapat diduga akibatnya, aturan hukum tersebut tidak dapat berjalan.
Dari sisi lain, apabila hukum tidak dirumuskan dengan jelas dan para pelaksana di lapangan pun tidak memahaminya, hal ini jelas akan berdampak pada mutu penegakan hukum tersebut.

Berkenaan dengan itu, selaras dengan apa yang dikemukakan oleh Bruggink bahwa begitu seseorang berusaha memahami tanda yang dihadapinya ketika membaca suatu peraturan hukum, maka yang bersangkutan telah berhubungan dengan bahasa dan kegiatan berpikir (Bruggink dalam Tahir, 2004: 3).

Berkenaan dengan masalah ini, Badudu mengatakan bahwa kondisi yang muncul dalam masyarakat mengakibatkan adanya anggapan bahwa bahasa hukum Indonesia tidak mengungkapkan keaslian bahasa Indonesia sehingga seolah-olah bahasa hukum itu adalah bahasa dengan corak sendiri yang tidak sejalan dengan bahasa umum yang digunakan oleh masyarakat. Dengan demikian, bahasa hukum menjadi bahasa yang sukar dipahami.

Harus diakui bahwa menulis dokumen hukum sama sekali bukan tugas yang ringan dan sederhana. Apalagi dokumen ini berupa keputusan dari suatu lembaga. Penulis dokumen tidak hanya dituntut untuk memahami ketentuan perundang-undangan yang menjadi landasannya, tetapi juga harus memiliki kemampuan dan keterampilan menggunakan bahasa Indonesia dengan baik dan benar (Harkrisnowo, 2003: 3).

Berdasarkan pengamatan penulis, berbagai masalah yang timbul dalam hal ini mencakup kebiasaan atau kecenderungan merumuskan atau menguraikan produk hukum dalam kalimat yang panjang dengan banyak anak kalimat dengan struktur kalimat yang kurang tepat. Sebagai contoh:

Seorang pembeli yang hendak menggunakan kekuasaan yang diperjanjikan di dalam persetuannya sewa, untuk, jika barangnya dijual, memaksa si penyewa mengosongkan barang yang disewa, diwajibkan mem peringatkan si penyewa sekian lama sebelumnya, sebagaimana diharuskan oleh adat kebiasaan setempat mengenai pemberhentian-pemberhentian sewa (Kitab UU Hukum Perdata). 
Sebagai bagian dari bahasa Indonesia, bahasa hukum selayaknya juga mengikuti bahasa Indonesia secara umum dan juga tidak membuka peluang terjadinya kesalahan struktur kalimat yang menyebab-kan kalimat tidak sesuai dengan kaidah bahasa Indonesia yang baik dan benar.

Bertolak dari latar belakang tersebut, objek yang diteliti adalah kesalahan penggunaan bahasa Indonesia pada dokumen tertulis yang berupa putusan ekonomi syariah dalam lingkup Pengadilan Agama Makassar. Alasan memilih putusan ini, karena merupakan perkara murabahah yang berarti salah satu bentuk jual beli barang pada harga asal dengan tambahan keuntungan yang disepakati dan termasuk dalam kajian perbankan syariah. Sejalan dengan hal itu, putusan ini berangkat dari perkara yang pertama kalinya di Sulawesi Selatan, sejak penyelsaian sengketa perbankan syariah dilimpahkan ke Pengadilan Agama berdasarkan Undang-Undang Nomor 21 Tahun 2008 Pasal 55.

Penelitian ini bertujuan untuk mendeskripsikan bentuk-bentuk kesalahan penggunaan bahasa Indonesia laras hukum dalam putusan ekonomi syariah pada Pengadilan Agama Makassar. Manfaat yang diharapkan dari hasil penelitian ini, untuk meningkatkan pengetahuan dan pemahaman tentang bahasa Indonesia laras hukum. Memberikan pemahaman dan pengetahuan tentang kesalahan kalimat yang terdapat dalam bahasa Indonesia laras hukum. Untuk memberikan sumbangsi pemikiran bagi kalangan hukum tentang penggunaan bahasa Indonesia yang baik dan benar, baik pada komunikasi tulis. Sebagai bahan referensial bagi calon peneliti yang ingin memperdalam kajian mengenai bahasa hukum dalam berbagai aspek.

\section{Metode Penelitian}

Penelitian ini mengacu pada penelitian deskriptif kualitatif. Penelitian ini bersifat dokumentatif atau penelitian pustaka (library research). Oleh karena itu, peneliti mendokumentasikan kesalahan pengunaan kalimat bahasa Indonesia laras hukum. Berdasarkan jenisnya, penelitian ini adalah penelitian deskriptif. Oleh karena itu, desain yang digunakan berdasarkan prinsip metode deskriptif kualitatif, yaitu mengumpulkan, mengolah, menganalisis, dan menyajikan data secara objektif.

Data dalam penelitian ini adalah penggunaan bahasa hukum dalam putusan ekonomi syariah nomor 73/Pdt.G/2015/ PA.Mks. pada pengadilan Agama Makassar. Pengumpulan data penelitian ini dilakukan melalui teknik dokumentasi, penelitian kepustakaan (library research) dilakukan dengan menelaah beberapa referensi tentang penguaan bahasa hukum, baik yang berupa buku, jurnal, majalah, koran, laporan hasil penelitian, maupun dokumen-dokumen hukum yang relevan dengan permasalahan yang diteliti. Pencatatan yaitu penulis mencatat semua hal yang berhubungan dengan fenomena pengunaan bahasa hukum, yang diperoleh dari putusan pengadilan Agama Makassar serta dokumen-dokumen yang relevan, ke dalam buku catatan yang telah dipersiapkan (Korpus).

Adapun langkah-langkah dalam menganalisis data penelitian ini, yaitu (1) Mengidentifikasi kalimat bahasa hukum yang mengalami kesalahan, (2) Mengklasifikasi bentuk kesalahan penulisan kalimat dalam putusan perkara ekonomi syariah Pengadilan Agama Makassar, (3) Menganalisis bentuk kesalahan pengunaan bahasa Indonesia yang berbentuk kalimat dalam putusan perkara ekonomi syariah Agama Makassar, (4) Mendeskripsikan setiap bentuk kesalahan penggunaan bahasa yang disertai uraian-uraian atau penjelasan.

\section{Hasil dan Pembahasan}

Pada bagian ini diuraikan data yang diperoleh tentang kesalahan struktur kalimat bahasa Indonesia laras hukum dalam putusan ekonomi syariah Pengadilan Agama Makassar. Adapun kesalahan struktur kalimat dapat diuraikan seperti tampak pada data berikut:

Data 1

PENGUGAT Dagama Islam, pekerjaan Wiraswasta, bertempat tinggal di kelurahan Pai, Kecamatan Biring-kanaya, Kota Makassar; dalam hal (ini) memberikan kuasa kepada: A Mahyanto mazda, S.H., M.H.A. Makagiansar, S.H. Muhammad Bazra, S.H. masing-masing advokat, berdasarkan Surat Kuasa 
Khusus No. 052/SK/AMM-SS/I/2005 tanggal 8 Januari 2015, selanjutnya disebut sebagai Penggugat." (PESPA.Mks., 2015: 1).

Berdasarkan data 1 di atas, dapat dikatakan mubazir dari segi pengunaan katanya. Hal itu dapat terlihat pada kata pengugat yang berulang tanpa menyebut nama atau inisial pengugat. Kata pengugat (pemberi kuasa) hanya disertai agama, pekerjaan, serta alamat, tanpa identitas lain. Sebagai akibatnya kalimat pada data 1 menjadi rancu. Selain itu, kalimat di atas mengalami kesalahan struktur yang disebabkan oleh penghilangan salah satu fungsi kalimat. Kesalahan yang dimaksud yaitu kehilangan fungsi subjek (S). Oleh karena itu, untuk mengindari terjadinya kesalahan struktur pada kalimat di atas, maka harus dilengkapi dengan fungsi subjek (pelaku).

Jadi, kalimat yang tepat dan tidak mengalami kesalahan struktur berdasarkan kalimat di atas, yaitu:

Si... beragama Islam, pekerjaan Wiraswasta, bertempat tinggal di kelurahan Pai, Kecamatan Biringkanaya, Kota Makassar; dalam hal ini memberikan kuasa kepada: A Mahyanto mazda, S.H., M.H. A. Makagiansar, S.H. Muhammad Bazra, S.H. masingmasing advokat, berdasarkan Surat Kuasa Khusus No. 052/SK/AMM-SS/I/2005 tanggal 8 Januari 2015, selanjutnya disebut sebagai Penggugat.

Data 2

BANK berkedudukan di Jakarta Pusat dalam hal ini diwakili oleh pimpinan Mikro-KCP BNI Syariat. selanjutnya disebut Tergugat. (PESPA.Mks., 2015: 1).

Berdasarkan data 2, terdapat akronim KCP (Kantor Cabang Pembantu) yang memiliki kesamaan arti dengan Cabang Mikro. Selain itu, pada data yang dimaksud terdapat tiga klausa, klausa pertama BANK berkedudukan di Jakarta Pusat, klausa kedua, yaitu dalam hal ini diwakili oleh pimpinan Cabang Mikro KCP BNI Syariah, dan klausa ketiga selanjutnya disebut Tergugat. Merujuk dari hal itu, tanda baca [,] seharusnya mengantarai klausa satu ke klausa dua dan tanda baca [;] yang mengantari klausa dua dengan tiga, semestinya mengunakan [,].

Dengan demikian, kalimat yang tepat dan tidak mengalami kesalahan tanda baca, sebagai berikut:

BANK berkedudukan di Jakarta pusat, dalam hal ini diwakili oleh pimpinan KCP BNI Syariah, selanjutnya disebut Tergugat.

Data 3

Membebankan kepada penggugat untul membayar biaya perkara sebesar Rp 411.000.00, (empat ratus sebelas ribu rupiah) (PESPA.Mks., 2015: 6).

Data 3 di atas termasuk kalimat majemuk yang ditandai oleh pemakaian kata depan 'untuk' menyatakan bagi, sebab atau alasan, menunjukkan tujuan atau maksud. Kalimat tersebut terdiri atas dua klausa, yaitu klausa utama dan klausa sematan. Klausa utama, yaitu membebankan dan klausa kedua sebagai kluasa sematan, yaitu terdakwa membayar biaya perkara sebesar $\mathrm{Rp}$ 411.000.00. Namun, kalimat di atas mengalami kesalahan struktur yang disebabkan oleh penghilangan salah satu fungsi kalimat. Fungsi yang tidak terdapat pada data (3) sehingga menyebabkan kalimat mengalami kesalahan struktur, yaitu fungsi subjek (S). Oleh karena itu, untuk menghindari terjadinya kesalahan struktur pada kalimat di atas, maka harus dilengkapi dengan fungsi subjek (pelaku).

Klausa di atas, dapat dianalisis berdasarkan struktur kalimat sebagai berikut:

$S$ : Pengugat, berkategori nomina, berperan sebagai pelaku

$\mathrm{P}$ : membayar, berkategori verba

$\mathrm{O}$ : biaya perkara, berkategori nomina, berperan sebagai sasaran

Ket. : sebesar Rp 411.000.00, (empat ratus sebelas ribu rupiah), berkategori numeralia, berperan sebagai sasaran

Dengan demikian, kalimat yang tepat dan tidak mengalami kesalahan struktur berdasarkan kalimat di atas, yaitu:

Membebankan kepada penggugat membayar biaya perkara sebesar Rp 411.000.00, (empat ratus sebelas ribu rupiah) 
Data 4

\section{Bahwa berdasarkan Akad pembiayaan Murabahah ergugat selaku nasabah dari tergugat memiliki kewajiban hutang yang harus dibayar (PESPA.Mks., 2015: 1).}

Data 4 di atas menunjukan kesalahan penempatan kata 'bahwa' dan kesalahan penalaran. Kata 'bahwa' merupakan kata penghubung antar kalimat. Artinya, kata tersebut dapat berada di tengah untuk menjelaskan klausa atau kalimat yang ada di depannya. Selain posisi di tengah, kata itu dapat saja berada di awal namun bertujuan menjelaskan pokok kalimat.

Selain kesalahan pengunaaan kata, pada data 4 di atas juga mengalami kesalahan penalaran. Kesalahan yang dimaksud dapat terlihat pada ...tergugat selaku nasabah dari tergugat...kata tergugat yang pertama semestinya diganti dengan pengugat. Sebagai akibat dari hal itu, kalimat menjadi rancu.

Dengan demikian, kalimat yang tepat dan tidak mengalami kesalahan struktur berdasarkan kalimat di atas, yaitu:

berdasarkan Akad pembiayaan Murabahah pengugat selaku nasabah dari tergugat memiliki kewajiban hutang yang harus dibayar.

Data 5

(Bahwa sebagat jaminan hutan Penggugat kepada Tergugat adalah sebidang tanah dan bangunan (rumah) milik Penggugat yang beralamat di Kelurahan Pai, Kecamatan Biringkanaya 9052 dengan bukti kepemilikan SHM No.20491 atas nama PENGGUGAT (PESPA.Mks., 2015: 2)

Data 5 di atas menunjukan tidak tepatnya pengunaan kata 'bahwa' berada diawal kalimat. Kata tersebut merupakan kata penghubung untuk menyatakan isi atau uraian kata atau kalimat yang berada di depannya, serta berfungsi sebagai kata penghubung untuk mendahului kalimat yang menjadi pokok kalimat. Selain kesalahan tersebut, data 5 juga mengalami kesalahan struktur akibat penggunaan unsur yang sama secara berurutan yang mengakibatkan kalimat menjadi rancu. Hal ini dapat dilihat pada kata 'bahwa' dan 'sebagai'. Berdasarkan fungsinya, kedua kata ini sama, yaitu samasama sebagai konjungsi.

Data 5 juga terlalu banyak mengulangi kata 'Penggugat'. Kata tersebut diulangi sebanyak tiga kali dalam satu kalimat. Kata tersebut sebaiknya tidak lagi muncul untuk menjelaskan jaminan hutang atas nama PENGGUGAT, karena telah dikatakan milik pengugat pada klausa sebelumnya. Kata 'pengugat' pada putusan juga diketik dengan cara capital secara utuh, yang tidak dibenarkan dalam penulisannya. Penulisan huruf capital secara utuh, hanya diperuntukkan untuk penulisan judul, Bab, dan akronim yang terwakili setiap fonem. Selain itu, terdapat kata yang memiliki arti yang sama seperti kepemilikan dan SHM. Akronim SHM (sertifikat hak milik) juga merujuk makna kepemilikan yang tidak semestinya disandingkan pengunaannya.

Dengan demikian, kalimat yang tepat dan tidak mengalami kesalahan struktur berdasarkan data 5 di atas, yaitu:

Sebagai jaminan hutang Penggugat kepada Tergugat adalah sebidang tanah dan bangunan (rumah) milik Penggugat yang beralamat di Kelurahan Pai, Kecamatan Biringkanaya 9052, SHM No.20491.

Data 6

Bahwa Penggugat telah menjalani kewajiban pembayaran hutang kepada Tergugat dalam bentuk angsuran tiap bulannya dan telah dilaksanakan pembayaran angsuran tiap bulankyd dengan total bulan yang telah (dijalani adalah 12 bulan dengan jumlah pembayaran sebesar $R p$ 83.400.000.00 (PESPA.Mks., 2015: 2).

Data 6 di atas juga tidak mengikuti kaidah. Kalausa berulang-ulang, pengunaan sufiks -nya kurang tepat, dan kata 'dijalani' yang perlu diganti menjadi 'dilewati', atau 'dilalui'. Klausa berulang yang dimaksud adalah '....angsuran tiap bulannya dan telah dilaksanakan pembayaran angsuran tiap bulannya...' pengunaan sufiks -nya pada kata 'bulannya', juga dikatakan kurang tepat dan mubazir. Sufiks-nya berfungsi untuk menjelaskan atau menekankan kata yang berada di depannya. Kata bulannya, tidak 
lazim diberikan penekanan, karena tanpa sufiks - nya kata yang ada didepannya 'bulan' dapat dipahami dengan baik. Jadi, penggunaan kata tiap bulan tanpa sufiks -nya telah benar, karena kata 'bulan' benda (nomina) telah menerangkan kata 'tiap' yang merupakan kata ulang tiap-tiap atau setiap, termasuk dalam kata bilangan distributif.

Pemakaian kosakatan yang sama maknanya dan berulang. Artinya, terdapat pemakaian kosakata ganda dalam kalimat yang tidak tepat pengunaannya. Kosakata ganda seperti 'bulan' dan kosakata bermakna sama terlihat pada kata jumlah dan total.

Dengan demikian, kalimat efektif yang yang tidak mengalami kesalahan struktur berdasarkan data 6 di atas, yaitu:

Bahwa Penggugat telah menjalani kewajiban pembayaran hutang kepada Tergugat dalam bentuk angsuran tiap bulan, selama 12 kali dengan jumlah pembayaran sebesar $\mathrm{Rp}$ 83.400.000.00

Data 7

Menerima permintaan banding dari penasihat hukum terdakwa dan jaksa penuntut umum (PESPA. Mks., 2015: 9).

Kalimat di atas hanya terdiri satu buah klausa yang ditandai oleh pemakaian fungsi predikat. Namun, dilihat dari strukturnya, kalimat tersebut mengalami kesalahan. Hal tersebut disebabkan oleh penghilangan salah satu fungsi kalimat, yaitu fungsi subjek. Diketahui bahwa penghilangan salah satu fungsi kalimat, terutama fungsi subjek, menyebabkan kesalahan pada kalimat yang bersangkutan, baik mengalami kesalahan struktur maupun makna.

Kalimat di atas dapat diubah menjadi kalimat yang berstruktur sesuai dengan kaidah bahasa Indonesia dengan menambahkan salah satu fungsi kalimat, yaitu fungsi subjek. Dengan demikian, kalimat yang tepat tampak berikut ini.

Terdakwa menerima permintaan banding dari penasihat hukum dan jaksa penuntut umum.

Struktur kalimat di atas dapat diuraikan berikut ini.

S : Terdakwa, berkategori nomina, berperan pelaku

$\mathrm{P}$ : menerima, berkategori verba
$\mathrm{O}$ : permintaan banding, berkategori nomina, berperan sasaran

Ket. : dari penasihat hukum dan jaksa penuntut umum

Data 8

Bahwa terhitung bulan Agustus 2014 hingga bulan September 2014 Tergugat tidak menjalankan angsuran Tersebut, hal ini terjadi dikarenakan dengan adanya permasalahan mengenai keterlambatan barang herupalmesin pembuat hata de coco, show case, esens, meja stainless, rak, jumlah waktu Keterlambatan 7 (tuju) bulan setelah ditandatanganinya Akad Pembiayaan murabahah ersebut, sehingga usaha yang dilakukan oleh pengugat tidak bisa berjalan dengan baik dan hal tersebut sangat mempengaruhp untuk Pengugat melaksanakan kewajibannya atas pembayaran kepada Tergugat. (PESPA. Mks., 2015: 2).

Kesalahan struktur kalimat seperti tampak pada data di atas disebabkan oleh pemakaian konjungsi bahwa yang tidak tepat penempatannya. Berdasarkan Tata Bahasa Baku Bahasa Indonesia, konjungsi bahwa termasuk konjungsi antarklausa yang berfungi menghubungkan klausa utama dengan klausa bawahan.

Kesalahan nalar pada penggalan kalimat '...Tergugat tidak menjalankan angsuran...' dalam amar putusan tersebut, bukan tergugat yang wajib membayar ang-suran melainkan pengugat, karena dalam hal ini tergugat adalah pihak yang memberikan pinjaman atau pembiayaan murabahah kepada tergugat.

Penulisan huruf miring bagi kata serapan asing, juga tidak diindahkan dalam penulisan amar putusan perkara ekonomi syariah yang dimaksud. Selain penulisan huruf miring, kata mempengaruhi yang tepat adalah memengaruhi. Penulisan tanda baca [:] perlu dipakai pada akhir suatu pernyataan pada data di atas, karena diikuti rangkaian atau pemerian '...berupa: mesin pembuat nata de coco, show case, esens, meja stainless, rak...'

Selain kesalahan nalar, kesalahan penulisan, dan kesalahan pengunaan konjungsi, pada data 8 di atas juga rancu karena 
pengulangan kata seperti 'tersebut' yang berarti sudah disebutkan (dikatakan, diceritakan, dsb) diulang sebanyak 3 kali, kata 'keterlambatan' diulang sebanyak dua kali. Demikian pula kata 'dikarenakan' yang mendapatkan konfiks di- -kan, pengunaan kata depan 'untuk' atau menyatakan bagi Pengugat, 'mengenai' kena pada sasarannya (tujuannya dsb), serta klausa 'atas pembayaran', tidak perlu dicantumkan, karena menyalahi prinsip kalimat efektif. Sebab, tanpa kata tersebut kalimat dapat dipahami dengan baik.

Dengan demikian, kalimat di atas diubah dengan menghilangkan kata yang sama artinya serta menghilangkan pemakaian konjungsi bahwa. Jadi, kalimat yang tepat yaitu:

Terhitung bulan Agustus 2014 hingga bulan September 2014 Tergugat tidak menjalankan angsuran, hal ini terjadi karena adanya permasalahan, keterlambatan barang berupa: mesin pembuat nata de coco, show case, esens, meja stainless, rak, selam 7 (tuju) bulan setelah ditandatanganinya Akad Pembiayaan murabahah, sehingga usaha yang dilakukan tidak bisa berjalan dengan baik dan hal tersebut sangat mempengaruhi Pengugat melaksanakan kewajibannya membayar kepada Tergugat.

Kesalahan struktur kalimat tampak pula pada kalimat berikut.

Data 9

Bahwa dikarendkan musyawarah mufakat dan upaya-upaya komunikasi yang telah disampaikan oleh pihak Pengugat tidak beralan sebagaimana hal yang diharapkan, bahkan karena keterlambatan pembayaran selama 3 (tiga) bulan atas angsuran kewajiban pembayaran hutang tersebut pihak Tergugat dengan serta merta melakukan pelelangan atas agunan rumah milik penggugat sebagimana di tunjuk dalam surat Tergugat Nomor 298/BNIs Mikro/Mks/XII/ 2014 (PESPA. Mks., 2015: 3).

Kalimat pada data 9 di atas, mengunakan kata 'bahwa' dan 'dikarenakan' berada di awal kalimat secara bersamaan dan berurutan. Penulisan kata tersebut secara bersamaan, dalam kaidah penulisan kalimat efektif tidak dibenarkan. Kata 'bahwa' berfungsi sebagai penghubung untuk menda- hului pokok kalimat atau penghubung antar kalimat yang bertujuan menyatakan isi. Terkhusus pada pengunaan kata 'dikarenakan', tanpa didahului subjek, secara struktur kalimat yang dibentuk menjadi benar, namun kalimat menjadi pasif. Proses yang dimaksud pada kata 'dikarenakan' mendapatkan tambahan prefiks di- yang berfungsi membentuk kata kerja, dan menyatakan makna pasif. Karena artinya yang menjadi sebab atau alasan, sebab, lantaran, atau disebabkan oleh. Sedangkan sufiks -kan berfungsi untuk membentuk kata kerja. Jadi, konpiks di-kan berfungsi membentuk kata kerja bentuk pasif dan menyatakan makna kausatif.

Kesalahan pengetikan juga terjadi pada putusan perkara yang telah disahkan dan dipublikasikan melalui direktori Mahkamah Agung melalui laman putusan. Mahkamah-agung.go.id, kesalahan yang dimaksud dapat dilihat pada data yang dibubuhi lingkaran dengan tulisan 'beralan'. Selain kesalahan pengetikan, penggunaan kata juga banyak mengalami kesalahan. Pengunaan kata 'bahkan karena' secara bersamaan yang masing-masing berarti 'bahkan' kata penghubung bagian kalimat dengan bagian yang lain atau kalimat dengan kalimat untuk menyatakan penguatan, lebih-lebih, dan malahan. Karena berarti yang menjadi sebab atau alasan, sebab, lantaran, atau disebabkan oleh. Jadi, kedua kata tersebut sama-sama berarti penguatan.

Dengan demikian, kalimat pada data 9 dapat diubah dengan menghilangkan kata yang sama maknanya serta menghilangkan pemakaian konjungsi bahwa. Jadi, kalimat yang tepat yaitu:

Karena musyawarah mufakat dan upayaupaya komunikasi yang telah disampaikan oleh pihak Pengugat tidak beralasan sebagaimana hal yang diharapkan, karena keterlambatan pembayaran selama 3 (tiga) bulan atas angsuran kewajiban pembayaran hutang tersebut pihak Tergugat dengan serta merta melakukan pelelangan atas agunan rumah milik pengugat sebagimana di tunjuk dalam surat Tergugat Nomor 298/BNIs Mikro/ Mks/XII/2014 
Data 10:

Bahwa perbuatan yang dinyatakan terbukti itu diatur dan diancam dengan pidana pasal 290 ke-2 KUHP (PESPA. Mks., 2015: 6)

Kesalahan struktur kalimat seperti tampak pada data di atas disebabkan oleh pemakaian konjungsi bahwa yang tidak tepat penempatannya. Menurut Tata Bahasa Baku Bahasa Indonesia, konjungsi bahwa menyatakan penegasan yang penempatannya tidak boleh berada di awal kalimat. Konjungsi bahwa termasuk konjungsi antarklausa yang berfungi menghubungkan klausa utama dengan klausa bawahan.

Dengan demikian, kalimat di atas diubah dengan menghilangkan pemakaian konjungsi bahwa pada awal kalimat. Jadi, kalimat yang tepat yaitu:

Perbuatan yang dinyatakan terbukti itu diatur dan diancam dengan pidana pasal 290 ke-2 KUHP.

Adapun struktur kalimat tersebut yaitu:

$\mathrm{S}$ : perbuatan yang dinyatakan terbukti itu, berkategori nomina, berperan pelaku

$\mathrm{P}$ : diatur dan diancam, berkategori verba

Ket. : dengan pidana pasal $290 \mathrm{ke}-2$ KUHP

Data 11

Menimbang, bahwa pada hari-hari persidangan perkara ini, Pengugat dan Tergugat maupun masanya masing-masing tidak atang hadir di persidangan, meskipun telah dipangil secara patut. (PESPA. Mks., 2015: 4).

Ditinjau dari pengunaan kata 'hari-hari', tidak sesui dengan konteks, karena persidangan perkara Pengugat dan Tergugat maupun kuasanya hanya dilakukan sekali. Jadi kata hari-hari tidak tepat digunakan. Berbeda halnya dengan pengunaan morfem /nya/ bentuk terikat yang merupakan varian pronomina persona ia/dia dan pronomina benda yang menyatakan milik, pelaku, atau penerima dalam hal ini Pengugat dan Tergugat. Morfem-nya diikuti dengan kata 'masing-masing' yang berarti tiap-tiap orang dan sama-sama berkategori pronominal. Sehingga, kalimat yang tepat perlu memilih salah satu untuk digunakan.

Selaras dengan pengunaan kata sama di atas, kata datang dan hadir juga dijumpai secara berdempetan pada data. Kesamaan makna dari kedua kata tersebut dapat mengakibatkan kalimat menjadi bertele-tele.

Kalimat di atas dapat diubah menjadi kalimat yang benar sesuai dengan kaidah bahasa Indonesia dengan memerhatikan konteks dan menghilangkan aspek yang tidak perlu dan dianggap sama, baik secara arti maupun jenis kata. Dengan demikian, kalimat yang tepat tampak berikut ini.

Menimbang, bahwa pada hari persidangan perkara ini, Pengugat dan Tergugat maupun kuasa masing-masing tidak hadir di persidangan, meskipun telah dipangil secara patut.

Data 12

Bahwo Pengugat telah berupaya berulangkali untuk menyelesaikan masalah ini secara musyawarah mufakat, bahkan menyangupi untuk menyelesaikan angsuran tersebut secara sekaligas dari total keseluruhan Jumlab angsuran Tersebmt Vaikarenak@ adanya kesangupan dari pihak kolega/keluarga yang hendak membantu Pengugat untuk menyelesaikan permasalahan hutang tersebut yang isadirealisasikan pada bulan Maret 2014. (PESPA. Mks., 2015: 3).

Kalimat di atas mengalami kesalahan struktur yang disebabkan oleh penghilangan fungsi predikat. Selain itu, kesalahan struktur kalimat juga disebabkan oleh pemakaian kosakata secara berurutan yang memiliki makna sama seperti: total, dan jumlah. Selain itu, Kalimat di atas juga terjadi kekurang tepatan diksi. Hal yang dimaksud dapat dilihat pada kata 'bisa' memiliki makna ganda (ambigu) yaitu mampu atau racun. Masalah yang sejenis juga terjadi pada kata 'secara musyawarah' yang dapat diganti menjadi melalui. Secara berarti sebagai, selaku sedangkan melalui berarti menempuh atau melewati, jadi diksi yang tepat adalah melalui. Karena bahasa Indonesia laras hukum harus jelas, maka pengunaan bahasa yang ambigu kiranya dihindari. 
Berdasarkan hal di atas, data 12 dapat diubah menjadi kalimat yang efektif berstruktur sesuai dengan kaidah bahasa Indonesia yang baik dan benar seperti berikut.

Pengugat telah berupaya berulangkali untuk menyelesaikan masalah ini melalui musyawarah mufakat, bahkan menyangupi untuk menyelesaikan angsuran tersebut sekaligus dari total keseluruhan, dikarenakan adanya kesangupan dari pihak kolega/keluarga yang hendak membantu Pengugat untuk menyelesaikan permasalahan hutang tersebut yang bisa direalisasikan pada bulan Maret 2014.

Data 13

Bahwo Pengugat telah Ђerusaha dan mengupayakan kepada Tergugat untul meminta keringanan untuk pembayaran kewajiban tersebut dilakukan penundaan pembayaran angsuran, adapun alasan penundaan tersebud sangat berdasar karena usaha yang sementara digeluti Pengugap belum berjalan normal yang mana hal tersebut diakibatkan oleh keterlambatan barang sebagaimana dimaksud pada poin 6 (enam). (PESPA. Mks., 2015: 4).

Kesalahan yang terjadi pada kalimat di atas yaitu kesalahan struktur. Hal tersebut disebabkan oleh penghilangan salah satu fungsi konjungsi diawal kalimat. Selain itu, kalimat di atas mengalami kesalahan struktur akibat pemakaian kata-kata secara berlebihan, seperti 'berusaha' dan 'mengupayakan'. Kalimat di atas dapat diubah menjadi kalimat yang berstruktur sesuai dengan kaidah bahasa Indonesia baku dengan melepaskan kata 'berusaha', karena memiliki kesamaan makna dengan 'mengupayakan'. Kelebihan pengunaan kata juga terjadi pada kata 'untuk' yang diulang sebanyak dua kali dan kata 'tersebut' yang diulang sebanyak tiga kali.

Berdasarkan hal di atas, data 13 dapat diubah menjadi kalimat yang efektif berstruktur sesuai dengan kaidah bahasa Indonesia yang baik dan benar seperti berikut.

Pengugat telah mengupayakan kepada Tergugat meminta keringanan pembayaran kewajiban untuk dilakukan penundaan pembayaran angsuran, adapun alasan penundaan tersebut sangat berdasar karena usaha yang sementara digeluti Pengugat belum berjalan normal sebagai akibat keterlambatan barang sebagaimana dimaksud pada poin 6 (enam).

\section{B. Pembahasan}

Berdasarkan penyajian hasil analisis data, dapat diuraikan secara rinci tentang kesalahan struktur kalimat bahasa Indonesia dalam putusan perkara ekonomi syariah Pengadilan Agama Makassar dalam penyusunan kalimatnya banyak mengalami kesalahan, baik dari kosakata yang digunakan maupun strukturnya. Dilihat dari penggunaan kosakatanya, terjadi kesalahan akibat ketidaktepatan menggunakan imbuhan pada fungsi predikat kalimat pasif. Hal tersebut menyebabkan bunyi dan makna kalimat menjadi rancu.

Selanjutnya, dalam putusan-putusan Pengadilan Agama Makassar, banyak pula ditemukan kesalahan struktur kalimat. Kesalahan struktur kalimat yang ditemukan terjadi akibat tidak adanya unsur subjek dalam kalimat. Penyusun putusan dalam menulis putusan tidak memperhatikan fungsi-fungsi sebuah kalimat. Hal ini tampak pada setiap kalimat yang ditulis terkadang mengabaikan fungsi subjek. Selain penghilangan fungsi subjek yang menyebabkan kesalaha struktur kalimat, tampak pula kesalahan akibat ketidak tepatan penempatan fungsi subjek. Banyak kalimat yang berada pada awal paragraf menggunakan konjungsi yang tidak pada tempatnya dalam kalimat. Berdasarkan penyajian hasil analisis data juga ditemukan penggunaan konjungsi secara berurutan. Seperti penggunaan konjungsi bahwa dan karena itu, yang ditulis menjadi bahwa karena. Penggunaan konjungsi seperti itu tentu saja menyalahi kaidah bahasa Indonesia yang baik dan benar.

Kesalahan pemakaian konjungsi bahwa ditemukan pula pada awal kalimat. Konjungsi bahwa berfungsi sebagai penegasan maksud dalam kalimat yang disampaikan dalam klausa utama. Dengan demikian, tampak jelas kesalahan penggunaan/penem- 
patan konjungsi bahwa pada awal kalimat yang tidak menjelaskan klausa utama, karena konjungsi tersebut sebagai penghubung antarklausa.

Selain masalah yang dikemukakan di atas, terdapat masalah lain terdapat kesalahan lain yang tidak sesuai tata penulisan seperti: penulisan tanda baca, diksi, ambiguitas, pengunaan kata mubazir, sebagai akibatnya kalimat menjadi rancu dan ber tele-tele, serta disesuaikan konteks perkara dengan pola penalaran yang tepat. Semua itu, tidak diperhatikan dalam pembuatan putusan. Padahal putusan perkara tersebut telah disahkan bersifat final dan mengikat serta dipublikasikan melalui direktori Mahkamah Agung melalui laman putusan. Mah kamahagung.go.id.

Berdasarkan hasil pengamatan, terdapat beberapa indikasi yang menyebabkan penyunan kalimat bahasa Indonesia laras hukum pada putusan perkara ekonomi syariah banyak mengalami penyimpangan. Penyusun/perumus putusan-putusan Pengadilan Agama Makassar tidak mematuhi atau mengabaikan kaidah penyusunan kalimat bahasa Indonesia yang baik dan Benar. Hal lain yang menyebabkan terjadinya penyimpangan adalah perumus/penyusun putusan Pengadilan Agama Makassar tidak mengetahui dan memahami kalimat yang sesuai dengan bahasa Indonesia baku. Penyusun/perumus putusan Pengadilan Agama Makassar menyusun kalimat atas kehendaknya saja, tidak mempertimbangkan ketepatan penempatan struktur, pengunaan tanda baca, diksi, ambiguitas, pengunaan kata mubazir, tanpa memerhatikan gejala kerancuan kalimat, konteks perkara, serta pola penalaran yang tepat. Indikasi lain yaitu kurangnya pemahaman tentang tata penulisan bahasa Indonesia. Dalam hal ini, tidak memahami tata cara penggunaan preposisi dan konjungsi bahasa Indonesia yang benar, penulisan tanda baca, diksi, ambiguitas, pengunaan kata mubazir, dan gejala kerancuan kalimat.

\section{Simpulan}

Berdasarkan penyajian dan pembahasan di atas, dapat disimpulkan bahwa kalimat bahasa Indonesia laras hukum dalam putusan perkara ekonomi syariah Pengadilan
Agama Makassar mengalami kesalahan struktur sebagai akibat tidak memiliki fungsi subjek dalam kalimat, pengunaan konjungsi yang tidak tepat, serta tidak memerhatikan penulisan tanda baca, diksi, kata bermakna ambiguitas, pengunaan kata mubazir, serta menyesuaikan konteks perkara dengan pola penalaran yang tepat. Sebagai akibat dari kesalahan tersebut, makna kalimat menjadi rancu sehingga sulit dipahami oleh pembaca. Selain itu, kesalahan struktur kalimat dapat menyebabkan perbedaan makna yang ditumbulkan dalam suatu putusan.

\section{Daftar Pustaka}

Alisjahbana, SutanTakdir, 1986. Tata Bahasa Baru Bahasa Indonesia. Jakarta: Dian Rakyat.

Badudu, J.S., 1993. Cakrawala Bahasa Indonesia. Jakarta: Gramedia Pustaka.

Bruggink, J.J.H. 1996. Refleksi tentang Hukum. Bandung: Citra Aditsya Bhakti.

Rustan, Edhy. Analisis Kesalahan Struktur Kalimat Bahasa Indonesia Laras hukum dalam Putusan-putusan Pengadilan Negeri Makassar. Skripsi. Makassar: FBS Universitas Negeri Makassar.

Harkisnowo, Harkistuti. 2003. Bahasa Indonesia sebagai Sarana Pengembangan Hukum Nasional. Makalah dalam Kongres Bahasa Indonesia VIII. Jakarta: Pusat Bahasa.

Hastuti, Sri. 1985. Permasalahan dalam Bahasa Indonesia. Cetakan Kedua. PT Intan.

Kansil, C.S.T. 1983. Praktik Hukum Peraturan Perundang-undangan di Indonesia. Jakarta: Erlangga.

Mahadi. 1979. Pembinaan Bahasa Hukum di Indonesia. Bandung: Rineka Cipta.

Moeliono, Anton. M., dkk. 1995. Tata Bahasa Baku Bahasa Indonesia. Jakarta: Balai Pustaka.

Ramlan, M. 1976. Ilmu Bahasa Indonesia: Suatu Tinjauan Deskripsi. Yogyakarta: CV Karyono Yogyakarta. 
176. Al Amwal, Vol I. No. 2 September 2016

Said, Ide D.M. 2004. Pemberdayaan Bahasa Indonesia Memperkukuh Persatuan dan Kesatuan Bangsa. Makalah Seminar Bulan Bahasa di Kabupaten Bulukumba. Makassar.

Sakri, Adjad. 1998. Ilmuan dan Bahasa Indonesia. Bandung: ITB.

Santoso, Kusno Budi. 1990. Problematika Bahasa Indonesia: Sebuah Analisis Praktis Bahasa Baku. Jakarta: Rineka
Cipta.

Tahir, Heri. 2004. Penggunaan Bahasa dalam Perspektif Hukum (Makalah Disajikan dalam Seminar Kebahasaan). Makassar: Himabsid FBS UNM.

Tarigan, Henry Guntur, dkk. 1988. Pengajaran Analisis Kesalahan Berbahasa. Bandung: Angkasa 